\title{
PARADIGMA TAFSIR MAQASIDI
}

\section{Sutrisno \\ Mahasiswa Pascasarjana UIN Sunan Kalijaga \\ Ibn.udien@yahoo.com}

\begin{abstract}
:
This article discusses the concept of maqasid-based interpretation known as al-tafsir al-maqashidi. This type of interpretation is one of the new breakthroughs of contemporary scholars in facing various limitations of existing interpretive methods. This method is built from the concept of maqasid which was only limited to doctrine, then developed into a method or paradigm of thinking and religion. This literary study, based on biblical studies, seeks to discover the construction of the maqasidi commentary by emphasizing the formulation of specific methods of interpreting the Qur'an. Disclosure of the deepest meaning (maqasid) of the Qur'an in order to succeed the mission of the Qur'an as a book of guidance that can provide solutions to the humanitarian problem that continues to grow allegedly became the hallmark of this model of tafsir.
\end{abstract}

Keywords: al-tafsir al-maqasidi, tafsir, maqasid, paradigm and methods

\begin{abstract}
Abstrak:
Artikel ini membahas tentang konsep penafsiran berbasis maqasid atau yang dikenal dengan al-tafsir al-maqashidi.Jenis tafsir ini salah satu terobosan baru sarjana kontemporer dalam menghadapai berbagai keterbatasan metode penafsiran yang ada. Metode ini dibangun dari konsep maqasid yang dulunya hanya sebatas doktrin,
\end{abstract}


kemudian dikembangkan menjadi sebuah metode atau paradigma berfikir dan beragama.Tulisan yang didasarkan studi kepustakaan ini berusaha menemukan konstruksi tafsir maqasidi dengan menekankan pada perumusan metode khusus dalam menafsirkan alQuran. Penyingkapan makna terdalam (maqasid) Alquran dalam rangka menyukseskan misi al-Quran sebagai kitab hidayah yang dapat memberikan solusi terhadap problematika kemanusiaan yang terus berkembang disinyalir menjadi ciri khas model tafsir ini.

Kata kunci: al-tafsir al-maqasidi, tafsir, maqasid, paradigma dan metode

\section{PENDAHULUAN}

Alquran Sejak diturunkan kepada Nabi Saw hingga kini, dinamika pemahaman terhadap makna Alquran senantiasa dilakukan. Aktivitas pemahaman ini tidak pernah mencapai titik final, karena akan selalu beriringan dengan tuntutan dan perkembangan zaman. Meskipun Alquran turun di Arab dengan konteks sosial budaya Arab pada masa itu, tetapi ia mengandung nilai-nilai universal yang akan selalu relevan untuk setiap zaman dan tempat. Alquran telah, sedang dan akan selalu ditafsirkan. Alquran memberikan kemungkinan-kemungkinan arti yang tak terbatas, sehingga ayat-ayatnya selalu terbuka untuk interpretasi baru, tidak pernah pasti dan tertutup dalam interpretasi tunggal. ${ }^{1}$

Sebagai suatu proses, pemahaman dan penafsiran Alquran menuntut adanya seperangkat metode dan pendekatan. Kebutuhan akan metode dan pendekatan merupakan suatu keniscayaan bagi diri seorang pengkaji Alquran. Terlebih adanya perbedaan-perbedaan yang cukup mendasar dan tak berujung dalam penggal sejarah manusia, serta kenyataan abadi yang dihadapi oleh Islam bahwa

\footnotetext{
${ }^{1}$ M. Quraish Shihab, Membumikan Al-Qur'an (Bandung: Mizan, 1989), h. 43.
} 
nash Alquran dan hadis terbatas secara kuantitatif, sementara peradaban (peristiwa hukum) selalu berkembang. ${ }^{2}$ Untuk itu diperlukan kreativitas dan inovasi yang berkesinambungan dalam metodologi memahami Alquran. ${ }^{3}$

Dengan demikian, dapat disinyalir bahwa usaha memahami maksud Alquran (tafsir) dan berbagai metodologi penafsiran yang telah ada merupakan salah satu disiplin ilmu yang senantiasa mengalami perkembangan mengikuti situasi sosial, budaya.ilmu pengetahuan dan peradaban manusia. ${ }^{4}$ Bahkan kemungkinan besar mengalami apa yang disebut oleh Thomas Khun sebagai pergeseran paradigma (shifting paradigm) ${ }^{5}$

Sebuah paradigma dalam setiap disiplin ilmu, memiliki asumsi, metode dan pendekatan tertentu yang berbeda dari paradigma ilmu yang lain. Paradigma merupakan sistem keyakinan dasar atau pandangan fundamental yang membimbing seseorang termasuk penafsir dalam memilih metode dan cara-cara yang secara ontologis dan epistimologis sangat fundamental. ${ }^{6}$ Keyakinan atau pandangan fundamental tersebut menjadi pijakan awal (starting

\footnotetext{
${ }^{2}$ Yudian Wahyudi, Ushul Fikih versus Hermeneutika, cet vi, (Yogyakarta: Nawasea Press, 2010), h.48.

${ }^{3}$ M Amin Abdullah, Falsafah Kalam di Era Postmodernisme, (Yogyakarta: Pustaka Pelajar, 1994), h. 227.

${ }^{4}$ Abdul Mustaqim dkk, Studi Al-Qur'an Kontemporer, (Yogyakarta: Tiara Wacana Yogya, 2002), h. ix.

${ }^{5}$ Menurut Thomas S Khun bahwa Setiap zaman tertentu memiliki karakteristik pengetahuan yang berbeda, sehingga tidak secara otomatis dapat berlaku untuk zaman selanjutnya. Paradigma lama sebagai ilmu yang dipandang normal dan berlegitimasi pada masanya gagal menjawab masalah-masalah baru yang timbul, dan selanjutnya hanya akan menerbitkan anomali-anomali. Keadaan seperti itu akan mengundang paradigma baru yang bisa menawarkan alternatif. Lihat Thomas S. Khun, The Structur of Scientific Revolutions, terj. Tjun Surjaman, (Bandung: Remaja Rosda Karya, 2012)

${ }^{6}$ Guba \& Lincoln, "Competing Paradigm in Qualitative Reaseach", dalam Denzin \& Lincoln, Handbook of Qualitative Reaseach (California: SAGE Pub., 1994), 105. Dalam Ali Mudlofir, Paradigma Tafsir Tarbawi, jurnal Al-Tahrir Vol.11, No. 2 November 2011, h. 263
} 
point) seseorang untuk melakukan kajian.Meski tidak selalu diungkapkan secara eksplisit oleh penulis karya tafsir, dalam penafsiran Alquran sejatinya keyakinan dasar berupa asumsi-asumsi serta pertimbangan-pertimbangan logis tentang teks Alquran sebagai objek studinya itu dapat ditemukan. ${ }^{7}$

Selanjutnya, dari ragam pijakan atau keyakinan dasar itu berimplikasi terhadap penentuan pendekatan (approach) dan metode yang relevan.Pendekatan menjadi sudut pandang (starting view) bagaimana suatu permasalahan didekati, dibahas dan dianalisis berdasarkan sudut pandang (ilmu atau teori) tertentu, sehingga menghasilkan kesimpulan. ${ }^{8}$ Sedangkan metode yang identik dengan arti 'cara' atau 'teknik', harus menjadi hal yang lebih teknis dan sejalan dengan pendekatan. Maka kaitannya dengan tafsir Alquran, pendekatan dimaksudkan sebagai cara memandang, membahas dan menganalisa teks al Qur'an dengan menggunakan ilmu-ilmu atau teori-teori tertentu sebagai alat bantu, sedangkan metode dimaksudkan sebagai cara yang ditempuh oleh mufassir untuk menemukan makna teks Alquran, sejalan dengan pendekatannya.

Gabungan dari adanya keyakinan dasar atau dikenal dengan asumsi, pendekatan dan metode yang diterapkan dalam menemukan makna teks Alquran, meniscayakan lahirnya sebuah paradigma tafsir yang berdasar pada jenis pendekatan dan metode yang ditempuh.Pada akhirnya, paradigma tafsir maqasidi disinyalir sebagai paradigma baru yang memilki konstruk berupa asumsiasumsi, pendekatan dan metode tersendiri dalam kajian ilmu tafsir.

\section{PENGERTIAN TAFSIR MAQASHIDI}

${ }^{7}$ Saifullah, Nuansa Inklusif Dalam Tafsir al-Manar (Jakarta: Badan Litbang dan Diklat Kemenag, 2012), h.33

${ }^{8}$ Moh. Nuhakim, Metodologi Studi Islam (Malang: UMM Press, 2006), h. 15 
Dalam kamus besar bahasa Indonesia, kata tafsir bermakna: keterangan atau penjelasan tentang ayat-ayat Alquran agar mudah dipahami. ${ }^{9}$ Namun pada dasarnya kata tafsir tidak berakar dari bahasa Indonesia murni, tetapi dari bahasa Arab yang berarti alidhahah (menerangkan) dan al-tabyin (menjelaskan). Asal usul kata tafsir bisa berasal dari kata al-Fasr atau al-Tafsarah.Kata al-Fasr sendiri berarti bisa bermakna al-Kasyf (menyingkap) dan al-izhar (menampakkan).Sedangkan kata al-Tafsarah merupakan istilah untuk sesuatu yang diperiksa oleh seorang d-okter dari pasiennya. ${ }^{10}$ Sedangkan dalam kamus al Munawwir, dikatakan bahwa tafsir merupakan bentuk masdar "tafsirotun" dari fi'il fassara-yufassiru yang memiliki banyak arti, diantaranya: menerangkan, menjelaskan, memberi komentar, menerjemahkan atau mentakwilkan. ${ }^{11}$

Secara istilah, tafsir memiliki beberapa defenisi. Misalnya tafsir didefenisikan dengan ilmu yang digunakan untuk menemukan pemahaman atas kitabullah yang diturunkan kepada nabi Muhammad saw.,untuk menjelaskan makna-maknanya, menetapkan hukum dan hikmahnya. ${ }^{12}$ Al-Zarkasyi mendefenisikan tafsir sebagai ilmu untuk memahami kitabullah yang diturunkan kepada Nabi Muhammad Saw, juga untuk menjelaskan makna-maknanya, mengungkap hukum-hukum dan hikmah-hikmah yang terkandung dalamnya didasari dengan ilmu bahasa, nahwu, tasrif, bayan, ushul fiqh, ilmu qira'ath dan juga pengetahuan terhadap asbab al-nuzul dan nasikh wa al-mansukh. ${ }^{13}$

${ }^{9}$ www.kbbi.web.id, diakses pada kamis 31 Agustus 2017, pukul 12.10

${ }^{10}$ Ibn Mandzur, lisan al- 'Arab, ditahqiq oleh Amir Ahmad Haidar, cet. Ke2, jilid V (Beirut: Dar al-Kutub al-'Ilmiah, 2009), h. 64-65.

${ }^{11}$ Ahmad Warson Munawwir, Kamus al-Munawwir, ( Indonesia : Pustaka Progressif, 1997), h. 1054

${ }^{12}$ Nashruddin Baidan, Wawasan Baru Ilmu Tafsir , (Yogyakarta: Pustaka Pelajar, 2005), h. 66.

${ }^{13}$ Badr al-Din Muhammad al-Zarkasyi, al-Burhan fi' 'Ulum al-Qur'an, juz ke-1 (Beirut: Dar al-Ma'rifah, 1957), h. 15. 
Sementara kata maqasidi (maqashidi) merupakan kata bentukan dari maqashid yang memiliki tambahan ya' nisbah yang bersandar padanya.Maqashid merupakan bentuk jamak dari kata maqshad yang bermakna maksud, sasaran, prinsip, niat, tujuan, tujuan akhir. ${ }^{14}$ Kata ini acapkali disamakan dengan kata al-hadaf, algharad, al-mathlub, dan al-ghayah., al-hikam, al-maani dan alasrar. $^{15}$

Pada dasarnya, kata maqhasid sering disandingkan dengan kata al-syari'ah yang membentuk susunan maqashidalsyari'ah.Namun dalam perkembangannya, kata maqashid tidak jarang disandingkan dengan kata Alquran yang membentuk frase maqashid Alquran.Frase ini menurut sebagian peneliti dianggap sebagai bentuk evolusi maqasid, akibat beberapa keterbatasan cakupan maqashid al-syari'ah sebagai frase lama yang tidak digali langsung secara holistik pada sumber pertama syariat. ${ }^{16}$ Sementara maqashid Alquran yang memuat seluruh teks Alquran, memiliki cakupan wilayah maqasid yang tidak hanya terbatas pada persoalan hukum fiqih saja, melainkan menyentuh apa saja yang dapat dikatakan sebagai perintah dan larangan tuhan, baik dalam tataran tingkah laku manusia maupun dalam akidah dan aspek-aspek lainnya dalam kehidupan manusia. ${ }^{17}$ Dengan demikian dapat dikatakan bahwa maksud daripada term maqashid Alquran adalah tujuan-tujuan luhur yang diperoleh dari sekumpulan hukum-hukum Alquran. ${ }^{18}$

\footnotetext{
${ }^{14}$ Jaser Auda, Membumikan Hukum Islam melalui Maqasid Syariah, terj. Rosidin dan Ali Abd Mun'im, (Bandung: Mizan, 2015), h.32

${ }^{15}$ Abdul Karim Hamidi, Al Madkhal ila Maqasid al-Qur'an, (Riyadh: Maktabah ar Rusyd, 2007), h.21

${ }^{16}$ Munawir, Pandangan Dunia Al-Qur'an; Telaah Terhadap PrinsipPrinsip Universal al-Qur'an, Penelitian Individual, (Purwokerto: IAIN Purwokerto, 2015), h. 57

${ }^{17}$ Halil Thahir, Ijtihad Maqasidi; Rekonstruksi Hukum Islam Berbasis Interkonesitas Maslahah (Yogyakarta: LKiS, 2015), h.16

${ }^{18}$ Abdul Karim Hamidi, h.27
} 
Selain masalah keterbatasan, definisi maqashid al-syari'ah yang bergerak teratur mengikuti perkembangan teorinya, ${ }^{19}$ sehingga setiap ulama ushul memiliki definisi yang berbeda antara satu dengan yang lainnya, menjadi sorotan tersendiri bagi kalangan para peneliti modern. Jika merujuk pada era klasik, tidak diketemukan definisi maqashid al-syari'ah secara komprehensif dan tegas dengan paparan yang tuntas, termasuk imam al-Syathibi yang tidak mengupas tentang defenisi untuk maqashid al-syari'ah. ${ }^{20}$ Pembicaraan maqashid al-syari'ah pada masa itu hanya dapat ditimba dari pemikiran para ulama tentang 'illah hukum dan mashlahah.

Definisi maqasid al-syari 'ah yang komprehensif lebih banyak dikemukakan oleh ulama-ulama kontemporer, seperti yang di defenisikan oleh Ibn 'Ashur dan A'lal al-Fasi. Menurut Ibn 'Ashur, maqashid al-syari'ah adalah makna-makna dan hikmah-hikmah yang diperhatikan dan dipelihara oleh al-Syari' (pembuat syariat) dalam setiap bentuk penentuan hukumnya. Hal ini tidak hanya berlaku pada jenis-jenis hukum tertentu sehingga masuklah dalam cakupannya segala sifat, tujuan umum dan makna syariat yang terkandung dalam hukum serta masuk pula di dalamnya makanmakna hukum yang tidak diperhatikan secara keseluruhan tetapi dijaga dalam banyak bentuk hukum. ${ }^{21}$ Sedangkan 'Alal al-Fasi

\footnotetext{
${ }^{19}$ Menurut Ahmad al Raysuni perkembangan maqasid dapat dikembalikan kepada tiga tokoh sentral yang berpengaruh yaitu Imam al Haramain Abu al Ma'ali Abd Allah al Juwayni (w. 478), Abu Ishaq al-Syatibi (w. 790) dan Muhammad al Tahir ibn Asyur (w. 1379 H / 1973 M). lihat Ahmad al-Raysuni, al-Bahs fi Maqasid al-syari'ah, h.4-5, dalam Ahmad Imam Mawardi, Fiqhi Minoritas; Fiqh al-Aqalliyat dan Evolusi Maqasid al-syari'ah dari Konsep ke Pendekatan (Yogyakarta: LKiS, 2010) h.190

${ }^{20}$ Ahmad al-Raisuni, Nazhariyyat al-maqashid 'inda al-imam al-Syathibi, (Libanon: al-Mussasah al-Jami'ah li Dirasat wa al-Nasyr wa al-Tauzi', 1992), h. 13

${ }^{21}$ Muhammad Tahir Ibnu 'Asyur, Maqasid al-Syari'ah al-Islamiyah, ed. Muhammad al-Tahir al-Misawi, Cet II (Yordania: Dar al-Nafais, 2001),h.49
} 
mendefenisikan sebagai tujuan syari'at dan rahasia-rahasia yang dibuat oleh al-Syari' pada setiap hukum syari'at itu.

Dari definisi dua tokoh kontemporer di atas tentang maqashid al syari'ah, hakekatnya secara tidak langsung menujukkan tidak adanya perbedaan antara istilah maqashid al-syari'ah dengan istilah maqashid Alquran. Sebagaimana yang dipegang oleh Jaser Auda dalam permasalahan ini, tanpa membedakan antara kedua istilah tersebut. $^{22}$

Dengan demikian al-tafsir al-maqashidi merupakan tafsir alQuran yang berorientasi pada realisasi tujuan -baik tujuan syariat (maqashid al-syari'ah) secara khusus maupun tujuan Alquran (maqashid Alquran) $^{23}$ secara umum- dengan pola memperhatikan

${ }^{22}$ Pernyataan tersebut didengar langsung dari Jaser Auda dalam kuliah umumnya yang diselenggarakan oleh jurusan IAT dan AFI Magister Fakultas Ushuluddin UIN Sunan Kalijaga di Gedung Teatrikal Dakwah pada tanggal 13 Februari 2017

${ }^{23}$ Beberapa ulama kontemporer yang memiliki rumusan maqasid alQur'an, diantaranya: Tahir Ibn Asyur mengusulkan Maqasid umum al-Qur'an adalah mengajarkan dan memperbaiki akidah, mengajarkan nilai-nilai akhlak yang mulia, menetapkan hukum-hukum syariat, menunjukkan jalan kebenaran kepada umat Islam (Siyasah al-Ummah), memberikan pelajaran dan hikmah dari kisah bangsa-bangsa terdahulu, pengajaran syari'at sesuai dengan perkembangan zaman, al-Targhib wa al-Tarhib, membuktikan kebenaran risalah Nabi Muhammad. Lihat. Tahir Ibn Asyur, Muqaddimah al Tahrir wa al Tanwir, vol 1, (Tunisia: Daar al-Tunusiyyah li al-nasyr, 1984), h.40-41. Yusuf al Qardhawi menyimpulkan maqashid al-Qur'an terdiri dari melestarikan keyakinan yang benar, menjaga harkat dan hak-hak asasi manusia, menyeru manusia untuk beribadah kepada Allah, menyucikan jiwa, memperbaiki nilai moral, membangun keluarga harmonis, memperlakukan kaum wanita secara adil, membangun bangsa Muslim yang kuat dan menyeru pada dunia yang kooperatif. Lihat Yusuf al Qardhawi, Kayfa Nata'amal Ma'a al-Qur'an, (Kairo: Daar al-Syuruq, 2000) Cet 3, h.73. Sementara Muhammad Chirzin merumuskan maqashid al-Qur'an terdiri dari; membersihkan akal dan jiwa dari syirik, mengajarkan kemanusiaan yang adil dan beradab, menciptakan persatuan dan kesatuan, mengajak manusia berpikir dan bekerja sama, membasmi kemiskinan material dan spiritual, melestaraikan kasih sayang dan keadilan sosial, menjadi washtiyyah dan moderat, menekankan peranan ilmu dan teknologi. Lihat Muhammad Chirzin, Kearifan AlQur'an, (Yogyakarta: Pilar Media, 2007), h.10-13. 
makna terdalam dari ayat-ayat Alquran dalam bentuk hikmah, sebab hukum, tujuan dan segala nilai yang bisa menjadi kemaslahatan bagi manusia dalam menjalani kehidupannya dan menyelesaikan problem-problem di setiap masa.

Menurut Wasfi 'Asyur, al-tafsir al-maqashid adalah salah satu corak tafsir yang pemaknannya mengarah pada visi al-Quran, baik universal maupun parsial, yang bertujuan untuk mewujudkan kemaslahatan manusia. ${ }^{24}$ Al-Atrash dan Abd Khalid memandang tafsir maqasidi sebagai salah satu bentuk penafsiran yang dilakukan dengan cara menggali makna yang tersirat dalam lafaz-lafaz Alquran dengan mempertimbangkan tujuan yang terkandung di dalamnya. ${ }^{25}$ Sedangkan menurut Jaser Auda secara sederhana mengatakan bahwa tafsir maqasidi adalah tafsir yang mempertimbangkan faktor maqasid yang berdasar pada persepsi bahwa Alquran merupakan suatu keseluruhan yang menyatu. Sehingga sejumlah kecil ayat yang berhubungan dengan hukum akan meluas dari beberapa ratus ayat menjadi seluruh teks Alquran. Surah dan ayat Alquran yang membahas tentang keimanan, kisah para Nabi, kehidupan akhirat dan alam semesta, seluruhnya menjadi bagian dari sebuah gambaran utuh. ${ }^{26}$

\section{SEJARAH PERKEMBANGAN TAFIR MAQASHIDI}

Al-Tafsir al-maqashidi adalah wacana baru yang muncul dalam diskursus ilmu tafsir.Namun secara genealogi, sejarah perkembangannya dapat dilacak berdasarkan perkembangan ilmu

${ }^{24}$ Wasfi 'Asyur Abu Zaid, at-Tafsir al-Maqashid li Suwar al-Qur'an alKarim, h. 7. Makalah disampaikan pada seminar yang diselenggarakan oleh Fakultas Usuluddin Universitas al-Amir 'Abd al-Qadir Aljazair pada tanggal 4-5 Desember 2013, dengan tema 'Fahm al-Qur'an bain an-Nash wa al-Waqi'. Diunduh dari www.alukah.net pada hari selasa, 11 April 201, pukul 10.16

${ }^{25}$ Radwan Jamal el-Atrash dan Nahswan Abdo Khalid Qaid, al-Jazur alTarikhiyyah li al-Tafsir al-Maqashidi li al-Qur'an al-Karim, Majallah al-Islam fi Asiya no. 1 (Malaysia: UII, 2011), h. 220.

${ }^{26}$ Jaser Auda, h.299 
maqashid.Berdasarkan sejarah ide tentang maksud atau tujuan tertentu yang mendasari perintah Alquran dan Sunnah, sabagaimana yang dipriodesasikan oleh Jaser Auda bahwa sejarah tersebut dapat dilacak hingga masa sahabat Nabi. ${ }^{27}$ Sebagai contoh, satu kasus yang sangat popular terjadi pada masa sahabat waktu itu, yaitu shalat Asar di Bani Quraidzah.Dimana Nabi mengirim sekelompok sahabat ke Bani Quraizah, ${ }^{28}$ dan memerintahkan mereka salat Asar disana. ${ }^{29}$ Batas waktu salat Asar hampir habis sebelum para sahabat tersebut tiba di Bani Quraizah. Lalu, para sahabat terbagi menjadi dua kelompok yang berbeda pandangan; kelompok pertama, mengambil sikap untuk segera melaksanakan shalat Asar karena waktunya sudah hampir habis sekalipun belum sampai di Bani Quraidzah, sedangkan kelompok kedua, bersikap untuk tetap berpegang pada instruksi Nabi SAW, yaitu tidak melaksanakan shalat Asar karena belum sampai di Bani Quraidzah walaupun waktu Asar sudah habis.

Alasan kelompok pertama untuk segera melaksanakan salat, karena mempertimbangankan maksud dan tujuan dari perintah Nabi

${ }^{27}$ Jaser Auda berusaha menyusun sejarah perkembangan ide maqasid berdasarkan pada masa munculnya pemikiran tokoh tentang maqasid. Dia mengklasifikasikan masa tersebut menjadi empat periodesiasi yaitu; pertama, periode pada masa sahabat, melalui ijtihad sahabat Nabi. kedua, periode permulaan muncul teori maqasid (sebelum abad ke $5 \mathrm{H}$ ). ketiga, masa para imam penggagas teori maqasid dalam balutan kajian ushul fikih (antara abad ke $5 \mathrm{H}-8$ H), keempat, periode kontemporer. Lihat Jaser, h. 41-60. Berbeda dengan Auda, Ahmad al-Raysuni membagi sejarah perkembangan maqasid berdasarkan pada perkembangan dari makna satu konsep maqasid ke konsep yang lain. Dia metahbiskan 3 tokoh sentral yang berpengaruh atas perkembangan konsep maqasid, yaitu Imam al Haramain Abu al Ma'ali Abd Allah al Juwayni (w. 478), Abu Ishaq al-Syatibi (w. 790) dan Muhammad al Tahir ibn Asyur (w. 1379 H / 1973 M). lihat Ahmad al Raysuni, Al Bahs fi Maqasid al-syari'ah, h.4-5, dalam Ahmad Imam Mawardi, Fiqhi Minoritas; Fiqh al-Aqalliyat dan Evolusi Maqasid al-syari'ah dari Konsep ke Pendekatan (Yogyakarta: LKiS, 2010) h.190

${ }^{28}$ Sekitar tahun ke -7 H. lokasinya beberapa mil dari Madinah.

${ }^{29}$ Selengkapnya sabda Nabi SAW tersebut bisa dibaca pada, Sahih AalBukhari, Kitab al-Maghaziy. 
agar supaya bergegas dalam perjalanan, bukan bermaksud menunda salat Asar. Sedangkan kelompok lain memahaminya secara lahir sebagaimana bunyi istruksi Nabi untuk melaksanakan shalat di tempat tujuan. Setelah kembali ke kota Madinah, para sahabat melaporkan cerita tersebut kepada Nabi, sedang Nabi meneguhkan kebenaran kedua pandangan para sahabatnya.

Dalam kasus lain yang menunjukkan penerapan pendekatan berbasis maqasid terhadap perintah Nabi, sebagaimana yang terjadi dalam ijtihad Umar bin Khattab ketika para sahabat memintanya untuk membagikan harta rampasan (ghanimah) yang diperoleh dari perang, dengan alasan perintah dalam Alquran yang secara jelas membolehkan para tentara mujahid memperoleh ghanimah. ${ }^{30}$ Akan tetapi, Khalifah Umar menolak usulan para sahabat tersebut, dengan berpedoman pada ayat Alquran lainnya yang lebih umum yang menyatakan maksud Allah SWT untuk tidak menjadikan harta kekayaan hanya terbatas pada kalangan tertentu saja. ${ }^{31}$ Dengan ini, Umar dan para pendukung pendapatnya mengambil sikap berbeda dari sahabat lainnya, dikarenakan penerapan pendekatan maqasid dalam konteks maqasid hukum khusus yaitu pemerataan ekonomi dan mengurangi kesenjangan antar kelas. ${ }^{32}$

\footnotetext{
${ }^{30}$ Misalanya QS. al-Anfal: 75 yang terjemahannya: "Dan orang-orang yang beriman sesudah itu kemudian berhijrah serta berjihad bersamamu maka orangorang itu termasuk golonganmu (juga). Orang-orang yang mempunyai hubungan kerabat itu sebagiannya lebih berhak terhadap sesamanya (daripada yang bukan kerabat) di dalam Kitab Allah. Sesungguhnya Allah Maha mengetahui segala sesuatu. Depag, al-Qur'an dan Terjemahannya,

${ }^{31}$ Sebagaimana disebutkan dalam QS. Hasyr: 7, yang terjemahannya: “Apa saja harta rampasan (fai') yang diberikan Allah kepada Rasul-Nya (dari harta benda) yang berasal dari penduduk kota-kota maka adalah untuk Allah, untuk Rasul, kaum kerabat, anak-anak yatim, orang-orang miskin dan orang-orang yang dalam perjalanan, supaya harta itu jangan beredar di antara orang-orang kaya saja di antara kamu. Apa yang diberikan Rasul kepadamu, maka terimalah dan apa yang dilarangnya bagimu, maka tinggalkanlah dan bertakwalah kepada Allah. Sesungguhnya Allah amat keras hukuman-Nya".

${ }^{32}$ Dikutip dari Jaser Auda, h.42
} 
Ijtihad para sahabat dari kasus diatas menunjukkan gambaran terhadap konsepsi dan ide maqasid dalam bentuknya yang sederhana telah diterapkan dimasa awal Islam.Sahabat Nabi tidak selalu menerapkan 'dalalah lafal' (dilalah al-lafz) dalam istilah para pakar usul fikih, yaitu implikasi langsung dari suatu bunyi bahasa atau nas, tetapi sahabat juga tidak jarang menerapkan implikasi praktis, yang dikenal dengan istilah 'dalalah maksud' (dilalah al-maqashid). Implikasi tujuan ini memungkinkan fleksibilitas yang lebih besar dalam memahami teks (nash) dan meletakkannya sesuai konteks situasi dan kondisi. ${ }^{33}$

Setelah periode sahabat, ide dan konsepsi mengenai maqashid mulai berkembang, sekalipun perkembangannya belum terlalu signifikan dan belum menjadi subjek (tofik) karya ilmiah tersendiri, hingga tiba masa para ahli usul fikih belakangan, yaitu antara abad ke $5 \mathrm{H}$ hingga $8 \mathrm{H}$. Namun paling tidak telah mewarnai pola pokir ulama hukum Islam pada saat itu dengan tampaknya pada beberapa metode penalaran yang digunakan oleh para imam mazhab tradisional, seperti penalaran melalui kias, istihsan dan pertimbangan kemaslahatan. ${ }^{34}$

Dalam kurung waktu ke $5 \mathrm{H}$ hingga $8 \mathrm{H}$, ide maqasid mulai dibahas dalam beberapa karya ulama (baca: ushul al-fiqh), sekalipun pembahasannya belum begitu jelas dan terkesan dikesampingkan, akibat penolakan mazhab teologi atas peranan akal dalam memahami nash. ${ }^{35}$ Namun dalam kurun waktu ini, tepatnya dipenghujung abad kedelapan, ide maqasid mengalami proses metamorfosis sempurna dengan hadirnya Abu Ishaq al-Syatibi. Dalam kitab al-Muwafaqat, dia berhasil menampilkan wajah baru konsep maqasid yang lebih dinamis dan aplikatif, termasuk penyusunan teori-teorinya secara lengkap, sistematis dan

\footnotetext{
${ }^{33}$ Ibid. h.44

${ }^{34}$ Ibid, h.46

${ }^{35}$ Ahmad Imam Mawardi, h. 186
} 
jelas.Dengan demikian, ulama-ulama ushul kemudian sepakat menjadikannya sebagai bapak atau pendiri maqashid al syari'ah. ${ }^{36}$

Beberapa ulama yang termasuk dalam periode ini sebelum disempurnakan oleh al-Syatibi, ${ }^{37}$ diantaranya; Imam al-Haramain Abu al-Ma'ali Abd Allah al-Juwayni (w. 478), meskipun dia tidak pernah menulis kitab yang spesifik membahas teori maqasid, namun beliau berhasil dalam mendeskripsikan dasar-dasar teori maqasid. Dalam kitab al-Burhan fi Usul al-Fiqh (Bukti Nyata tentang Asas Metode Hukum Islam) dia menyebutkan adanya lima jenjang dalam maqasid yaitu: al-darurat (keniscayaan), al-hajat al-amah (kebutuhan publik), al-makrumat (perilaku moral), al-mandubat (anjuran-anjuran) dan apa yang tidak dapat dicantumkan pada alasan khusus. ${ }^{38}$

Upaya Imam al-Juawayni kemudian dilanjutkan oleh salah seorang muridnya, Abu Hamid al-Ghazali (w. 505 H/ 1111 M). Dia berhasil dalam mengelaborasi kajian maqasid Imam al-Juwayni yaitu dengan menjabarkan konsep al-daruriyat yang diperkenalkan oleh gurunya menjadi al-daruriyyat al-khams dengan mengurutkannya menjadi; keniscayaan keimanan, jiwa, akal, keturunan dan harta dengan menambahkan istilah al-hifz (pelestarian) pada setiap keniscayaan itu. Dia memproritaskan keniscayaan yang berkedudukan lebih tinggi dari pada yang lebih rendah apabila terjadi pertentangan diantara keduanya. ${ }^{39}$

\section{Cet. 1 , h. 35}

${ }^{36}$ Satria Effendi M. Zein, Ushul Fiqih, (Jakarta: Prenada Media, 2005),

${ }^{37}$ Menurut Jaser Auda, al-Syatibi telah menyempurnakan teori maqasid dalam tiga cara substansial berikut: Pertama, maqasid yang semula sebagai bagian dari kemaslahatan mursal (al-masalih al-mursalah) menjadi bagian dari dasar-dasar hukum Islam. Kedua, dari hikmah dibalik hukum menjadi dasar bagi hukum. Ketiga, dari ketidakpastian (dzanniyah) menuju kepastian (qat'iyah). Lihat Jaser Auda, h. 55.

\footnotetext{
${ }^{38}$ al-Juwayni, dalam Jaser Auda, h. 50.

${ }^{39}$ Jaser auda, Maqasid untuk pemula h. 41-42
} 
Selain dua tokoh diatas, beberapa tokoh lainnya yang memiliki kontribusi terhadap perkembangan teori maqasid, diantaranya; al-Izz Ibn Abd al-Salam (w. 660 H/ 1209 M) dalam kitab Qawaid al-Ahkam fi Masalih al-Anam beliau telah menginvestigasi secara ekstensif tentang konsep mashlahah dan mafsadah. Secara ringkas menurut dia, kemaslahaan dalam suatu permasalahan tidak boleh disia-siakan sebagaimana kemafsadatan yang ada didalamnya juga tida boleh didekati walaupun dalam masalah tersebut tidak ada ijma, nash dan qiyas yang khusus. ${ }^{40}$ Syihab al-Din al-Qarafi (w. 684 H / $1285 \mathrm{M}$ ) dalam kitab al-Furuq telah menulis tentang pembukaan sarana untuk meraih kemaslahatan (fath al zara'i), bahwa sebagaimana sarana yang mengarahkan pada tujuan haram harus ditutup, maka sarana yang mengarahkan pada tujuan halal seharusnya dibuka. ${ }^{41}$ Terakhir ada Syams al-Din ibn al-Qayyim (w. 7488 H / 1347 M) dengan metodologi yuridisnya berdasarkan 'hikmah dan kesejahteraan manusia'.Menurutnya, syariah didasarkan pada kebijaksanaan demi meraih keselamatan manusia di dunia dan di akhirat, dengan demikian syariah seluruhnya terkait dengan keadilan, kasih sayang, kebijaksanaan dan kebaikan. ${ }^{42}$

Pasca kemunculan al-Syatibi dengan karya monumnetalnya al-Muwafaqat, ide dan konsep maqasid mengalami kebuntuan perkembangan sekian lama, terpendam sekitar enam abad dalam kemandegan keilmuan, sampai akhirnya pada era kontemporer, terkhusus oleh Ibn 'Asyur yang menjadikan ilmu maqasid sebagai disiplin ilmu yang mandiri, sekaligus menjadikan disiplin ilmu yang

${ }^{40}$ Al-Izz bin Abd al-Salam, Qawaid al Ahkam fi Mashalih al Anam, (Damshiq: Dar al-Kutub al-Ilmiyyah, 1992), vol 2, h. 160.

${ }^{41}$ Sebagaimana dikutip Jaser Auda dalam Syihab al Din al Qarafi, Al Furuq (Ma'a Hawamisyihi), ed Khalil Mansur (Beirut: Dar al-Kutub al-Ilmiyyah, 1998), vol 1, h.357

${ }^{42}$ Syams al-Din Ibn al-Qayyim, I'lam al Muwaqqi'in, ed Taha Abdul Rauf Sa'd (Beiru: Dar al Jil, 1973), vol 1, h.333 
lengkap secara konseptual, prinsip dan metodologinya. ${ }^{43}$ Bersamaan dengan itu, beberapa cendekiawan kontemporer lainnya berhasil melakukan perbaikan dan perluasan jangkauan mengingat berbagai wujud kritikan terhadap klasifikasi dan konsep maqasid yang telah ada dan berkembang pada masa sebelumnya. ${ }^{44}$

Beberapa alasan perlunya dilakukan reformasi konsep maqasid tradisional sebagaimana berikut: Pertama, jangkauan maqasid tradisional meliputi seluruh hukum Islam, namun tidak memasukkan maksud khsusus dari suatu atau sekelompok nas/hukum yang meliputi topik fikih tertentu. Kedua, maqasid trasdisional lebih berkaitan dengan individu, dibandingkan keluarga, masyarakat atau umat manusia.Ketiga, klasifikasi maqasid tradisional tidak memasukkan nilai-nilai yang paling umum seperti keadilan dan kebebasan.Keempat, maqasid tradisional dideduksi dari kajian literatur fikih, ketimbang sumber-sumber syariat (Alquran dan sunnah). ${ }^{45}$

Perbaikan pada ruang lingkup maqasid diharapkan agar jangkauan orang yang diliputi oleh maqasid dapat menjangkau wilayah yang lebih luas. Sehingga nantinya dari perluasan jangkauan ini akan merubah titik tekan dari kinerja maqasid, dari titik tekan maqasid lama sekedar protection (perlindungan) dan preservation (penjagaan), mengarah pada titik tekan maqasid baru pada development (pengembangan) dan right (hak-hak). ${ }^{46}$

Demikian halnya perbaikan pada sumber induksi maqasid diharapkan dapat menjadi amunisi terbaru dalam merespon tantangan zaman, dengan memposisikan maqasid tidak hanya berfokus pada pemahaman atas ayat hukum yang sebagian besar digali dari literatur fikih dalam mazhab-mazhab fikih, tetapi meluas

\footnotetext{
${ }^{43}$ Imam Mawardi, h.197.

${ }^{44}$ Jaser Auda, h.38

${ }^{45}$ Ibid,. h. 36

${ }^{46}$ Ibid, h.56-57.
} 
pada penggalian secara langsung pada keseluruhan teks-teks suci keislaman, yaitu Alquran dan hadis Nabi SAW. Terlebih persoalan hukum hanya menempati sebagian dari ruang yang tersedia dalam Islam.Alquran selain mengandung persoalan hukum, juga berisi penjelasan tentang hari akhir, etika, fenomena alam, kisah umat terdahulu dan penjelasan tentang sifat-sifat Allah.

Berdasarkan dari perbaikan kedua aspek diatas, yaitu ruang lingkup dan sumber induksi, ulama kontemporer disamping berhasil merumuskan klasifikasi baru tentang maqasid, ${ }^{47}$ juga telah menjadikan ilmu maqasid sebagai salah satu media intelektual dan metodologi masa kini yang terpenting untuk reformasi islam, karena maqasid merupakan representasi sudut pandang masing-masing cendikiawan untuk mereformasi dan mengembangkan hukum Islam. ${ }^{48}$ Pada posisi demikian, ilmu maqasid berubah menjadi sebuah metode berpikir dalam diskursus keagamaan, termasuk metode dalam menafsirkan teks agama yang dikenal dengan at tafsir al maqashidi.

Sebagai pendekatan metodologis, maqasid kemudian menjadi trend baru yang diminati oleh banyak cendekiawan kontemporer, khususnya dalam bidang penafsiran Alquran. Seperti Ibn 'Asyur, Qardhawi, Muhammad al-Ghazali, Mahmud Syalthut, Rasyid Ridha, dan lain sebagainya.Berbagai seminar dan kajian juga diselenggarakan di berbagai daerah, seperti seminar yang membahas tentang bagaimana Alquran dan Hadis bisa ditafsir ulang

${ }^{47}$ Pada era kontemporer, klasifikasi maqasid terbagi menjadi tiga, yaitu; pertama, Maqasid umum (al maqasid al ammah) yang dapat ditelaah diseluruh bagian hukum Islam, seperti keadilan, kemudahan dan kebebasan. Kedua, Maqasid khusus (al maqasid al khassah) yang dapat diobservasi di seluruh isi bab hukum Islam tertentu, seperti kesejahteraan anak dala hukum keluarga. Ketiga, Maqasid parsial (al maqasid al juziyyah) meliputi apa yang dianggap sebagai maksud ilahi dibalik suatu nas atau hukum tertentu, seperti larangan menyimpan daging pada hari raya qurban dengan maksud member makan kepada orang miskin. Lihat Jaser Auda, h. 36

${ }^{48}$ Ibid, h. h0 
dengan menggunakan realitas kontemporer sebagai pertimbangan dan upaya mempromosikan tujuan syariat yang berpihak pada kedamaian, keadilan dan kemajuan umat Islam. ${ }^{49}$

Istilah tafsir maqasidi pertama kali dipopulerkan pada wacana Seminar Internasional dengan tema 'Metode alternatif Penafsiran' diadakan di kota Oujda, Maroko pada tanggal 18-20 April 2007. Kajian tafsir maqasidi sebenarnya pernah diangkat secara tuntas oleh Nuruddin Qirath dalam disertasi doktornya (di Universitas Muhammad V) yang mengangkat tema tentang 'Tafsir Maqasidi Menurut Perspektif Ulama Maghrib Arabi', begitu juga oleh professor Jelal al-Merini dari universitas al-Qurawiyien dalam bukunya Dhowabit al-Tafsir al-Maqashidi li Alquran al-Karim (ketentuan tafsir maqashidi terhadap Alquran), dan Hasan Yasyfu, dosen senior di universitas Oujda, Maroko, dalam bukunya alMurtakazaat al-Maqashidiyyah fi Tafsir an-Nash al-Din (penekanan sisi maqashid dalam menafsiri teks keagamaan), namun sebagai pendongkrak ide yang dituangkan melalui karya-karya tulis mereka ini, komunitas ulama intelektual, dan akademisi Maroko bahu membahu mensosialisasikannya melalui symposium ilmiah internasional pada bulan April 2007 tersebut. ${ }^{50}$

\section{URGENSI TAFSIR MAQASHIDI}

Dalam menemukan titik urgensi tafsir yang berbasis maqasid, hal itu dapat terlihat dari pengkajian urgensi antara tafsir dengan kajian maqasid. Secara mendasar, kebutuhan akan tafsir Alquran terasa sangat besar, mengingat tidak semua ayat Alquran memiliki ungkapan yang bisa dipahami langsung oleh akal manusia. Diantaranya ada yang memiliki lafaz yang samar (mutasyabih) sehingga terbuka untuk beberapa kemungkinan penafsiran, ada yang

\footnotetext{
${ }^{49}$ Imam Mawardi, h. 202

${ }^{50}$ Umayah, Tafsir Maqashidi; Metode Alternatif Dalam Penafsiran AlQur'an, jurnal Diya al-Afkar Vol.4 No.01, Juni 2016, h. 43
} 
memiliki kandungan yang bersifat global (mujmal) sehingga diperlukan perincian lanjutan untuk memahaminya. Terlebih dengan perbedaan dan perkembangan situasi dan kondisi pada era kontemporer ini, suatu keharusan bagi ulama tafsir untuk menafsirkan Alquran yang disesuaikan dengan realitas kehidupan masyarakat yang selalu dinamis, termasuk menawarkan metode baru dalam penafsiran Alquran.

Sedangkan titik urgensisitas kajian maqasid dapat dilacak berdasarkan proses perkembangannya, mulai dari masa klasik hingga kontemporer yang telah menjadikan maqasid sebagai satu metode berfikir dan beragama. Berawal dikalangan para imam mazhab, kajian yang memiliki nafas maqasid sangat intens diterapkan dalam penggalian hukum Islam. Seperti, mazhab Hanafi dengan metode istihsan, Maliki dengan maslahah al-mursalah dan Hanbilah dengan sad al-zara'i, ${ }^{51}$ sementara dari kalangan Syafi'iyah lebih cenderung memiliki pandangan yang sama dengan pendukung mazhab Zahiriyyah yang memandang esensi syariat hanya beredar pada teks normatif; Alquran, Hadits, Ijma' dan dalam metode qiyas. $^{52}$

Selanjutnya periode pasca imam mazhab, diantarannya Imam al-Juwayni yang memandang kajian maqasid sebagai prinsip fundamental yang menjadi dasar pijakan bagi seluruh hukum islam, sangat penting untuk diaplikasikan, karena tanpanya akan menyebabkan terjadinya benturan keras di kalangan ulama, bahkan mereka para fakih dan mazhab-mazhab fikih yang tidak mengindahkan prinsip tersebut pada akhirnya akan lenyap di bumi. ${ }^{53}$ Imam al-Ghazali sebagai murid dari al-Juwayni melanjutkan sikap gurunya dengan menitiberatkan pada

${ }^{51}$ Abdullah bin Bahyyah, 'Alaqah Maqashid al-syari'ah bi Ushul al-Fiqh (London: al-Furqan Islamic Heritage Foundation, 2006), h.45

${ }^{52}$ Ibid, h.44

${ }^{53}$ Al-Juwayni dalam Jaser Auda, h.51 
perlindungan (hifz) lima unsur pokok yang dikenal dengan ushul alkhamsah, yaitu menjaga agama, jiwa, akal, nasab dan harta sebagai prinsip fundamental. Hanya saja al-Ghazali masih terpengaruh oleh mazhab Syafi'iyyah yang tidak memperhitungkan maqasid sebagai metode ijtihad yang sah, sehingga terkesan tidak profesional karena menolak memberikan hujah atau legitimasi indipenden bagi teori maqasid yang ia tawarkan. ${ }^{54}$

Selanjutnya ada tokoh Imam al-Izz bin Abdul al-Salam yang secara tegas menghubungkan validitas hukum dengan maqasidnya, dia mengatakan bahwa setiap amal yang mengabaikan maqasidnya adalah batal. Barang siapa yang memperhatikan maqasid syariat, yaitu dalam upaya mendatangkan maslahat dan menolak mafsadat, ia akan memperoleh keyakinan dan pengetahuan yang mendalam bahwa mashlahat tidak boleh diabaikan dan mafsadat tidak boleh didekati, kendatipun tidak ada ijmak, teks maupun qiyas yang khusus membahasnya. ${ }^{55}$ Imam Syihab al-Din al-Qarafi mengembangkan teori sad al-zara'i dengan teori fath al-zara'i, bahwa apabila sarana yang mengarahkan pada tujuan haram harus ditutup, maka sarana yang mengarahkan pada tujuan halal seharusnya dibuka. ${ }^{56}$ Ibn al-Qayyim di dalam kitabnya "I'lam alMuwaqqi'in 'an Rabb al- 'Alamin" menyatakan bahwa seorang tidak akan mengetahui mana qiyas yang benar dan mana qiyas yang salah tanpa mengetahui rahasia-rahasia dan tujuan-tujuan syari' at. ${ }^{57}$

Urgensisitas maqasid semakin terang dengan hadirnya Imam al-Syatibi yang menjadikan pemahaman terhadap maqashid alsyari'ah sebagai syarat untuk berijtihad. ${ }^{58}$ Dalam artian, seseorang

\footnotetext{
${ }^{54}$ Ibid

${ }^{55}$ Ibid

${ }^{56}$ Ibid

${ }^{57}$ Ibn al-Qayyim, dalam Imam Mawardi. Fiqh Minoritas (Yogyakarta: LKiS, 2010), h.184

${ }^{58}$ Al-Syatibi, dalam Asafri Jaya Bakri, Konsep Maqashid al-Syariah Menurut al-Syatibi, (Jakarta: Raja Grafindo, 1996), h. 129
} 
tidak mungkin mencapai derajat ijtihad jika tidak mengetahui maqashid al-syari'ah secara sempurna dan menjadikannya sebagai metode penggalian dan penetapan hukum, termasuk penggalian terhadap permasalahan-permasalahan hukum yang tidak ditemukan secara jelas dimensi kemaslahatannya dapat dianalisis melalui metode maqasid tersebut.

Hanya saja tawaran konsep maqasid al-Syatibi masih menyisahkan celah bagi generasi berikutnya untuk melakukan kritik dan perbaikan. Sebagaimana diketahui bahwa al-Syatibi dalam membahas kemaslahatan, disamping masih bertumpu pada pemeliharaan lima unsur pokok setiap individu, juga hanya berkutat pada hirarki kekuatannya, yakni maslahah daruriyyat (mendesak, primer), maslahah hajiyyat (dibutuhkan, sekunder), dan maslahah tahsiniyyat (keindahan, tersier). Pengabaian aspek daruriyyat dapat merusak kehidupan manusia dunia dan akhirat secara keseluruhan. Tidak terwujudnya aspek hajiyyat tidak sampai merusak keberadaan lima unsur pokok, akan tetapi hanya membawa kepada kesulitan bagi manusia sebagai mukallaf dalam merealisasikannya. Sedangkan aspek tahsiniyyat yang terabaikan hanya membuat pemeliharaan lima unsur pokok tidak sempurna. ${ }^{59}$

Oleh karena itu, pada masa kontemporer, dimensi kemaslahatan tidak hanya bersifat proteksi dan pelestarian tetapi lebih bersifat pengembangan dan pemuliaan, sebagaimana tidak hanya diarahkan pada kepentingan individu melainkan dapat menjangkau kepentingan manusia yang lebih luas, yaitu masyarakat, bangsa bahkan umat manusia.Seperti meliputi prinsipprinsip utama yang lebih memiliki cakupan luas, misalnya keadilan, kebebasan berekspresi dan lain-lain ${ }^{60}$ Kemaslahatan juga tidak cukup diukur berdasarkan hirarki kekuatannya, tetapi meniscayakan adanya upaya interkonseksitas dan keterkaitan antar

\footnotetext{
${ }^{59}$ Ibid, h.72

${ }^{60}$ Jaser Auda, h.37
} 
maslahah. ${ }^{61}$ Dengan begitu dimensi kemaslahatan yang menjadi ruh dari maqasid al-syari'ah semakin terlihat perannya setelah dilakukan berbagai perbaikan dan perluasan cakupan maqasid, hingga akhirnya di era kontemporer ini, maqasid telah berevolusi menjadi sebuah metode berfikir dan beragama.

Salah satunya adalah metode yang dikembangkan ulama kontemporer dalam menafsirkan Alquran dengan mempertimbangkan sisi maqasid ayat, yang dikenal dengan alTafsir al-Maqashidi. Metode tafsir ini merupakan salah satu terobosan baru atas fenomena keterbatasan dan kekurang objektifan metode penafsiran yang telah ada.

Suatu penafsiran dianggap memiliki keterbatasan bilamana diyakini bahwa apa pun yang dikemukakan oleh umat Islam awal tentang tafsir merupakan pembacaan yang paling sah dan otoritatif, sehingga segala hasil penafsiran mereka harus diikuti pada zaman modern tanpa memperhatikan kondisi yang telah berubah. ${ }^{62}$ Akibatnya, pemahaman yang muncul cenderung tekstualis-literalis dan memiliki fungsi yang terbatas pada proses kontekstualisasi.

Sementara kontekstualiasi yang ditawarkan oleh para penafsir kontekstual dengan berusaha mempertimbangkan isu kemanusiaan dan titik kesejarahannya, meliputi sosial, politik dan budaya masyarakat, dianggap tidak dapat mempertanggung jawabkan secara objektif ketika terjadi pertentangan antara konteks manusia dengan teks syariat. ${ }^{63}$ Bahkan produk metode ini dinilai terlalu over subjektif, sehingga tak jarang mengantarkan pada sikap narsisistik bahwa pandangan subjektif manusia adalah pusat segala hal.Tanpa ada kontrol dan tolak ukur kebenaran, acap kali

${ }^{61}$ Halil Thahir, h.78

62 Abdullah Saeed, Paradigma, Prinsip dan Metode Penafsiran Kontekstualis atas al-Qur'an, terj. Lien Iffah (Yogyakarta: Lembaga Ladang Kata, 2015), h99

${ }^{63}$ Ahmad al-Raysuni, Ijtihad antara Teks, Realitas dan Kemaslahatan Sosial, terj. Ibnu Rusydi, (Jakarta: Erlangga, 2002), h.32 
paradigma seperti ini mengantarkan pada sikap arbitrer (sewenangwenang) dalam menafsirkan Alquran.

Dengan demikian, usaha untuk menghadirkan metode dan cara pandang baru yang tidak hanya mengandalkan pemahaman umat Islam awal atas teks dengan ciri pendekatan linguistik yang ketat, begitupun tidak menjadikan perkembangan zaman dan pengalaman manusia sebagai tolak ukur yang final, adalah merupakan suatu kebutuhan sekaligus menjadi alternaif baru dalam menafsirkan Alquran. Cara pandang maqasidi yang menekankan pada pencarian makna terdalam ayat-ayat Alquran dalam bentuk hikmah, sebab hukum, ketentuan hukum, dan segala aspek yang bisa mengantarkan pada pembentukan nilai mashlahat, serta menjadikan kehendak dan ketentuan syara' bukan kehendak dan tujuan manusia sebagai patokan dan tolak ukuran kemaslahatan tersebut, dapat menjadi alternatif dalam merespon keterbatasan paradigma penafsiran yang ada. Model penafsiran ini berusaha memelihara pesan universal Alquran, sehingga dapat lebih sesuai dengan tantangan dan tuntutan zaman (salihun li kulli zaman wa makan) dengan cara mengalihkan arah pandangan dengan melakukan pencarian pada maqașid Alquran yang universal. ${ }^{64}$

Nilai universal yang melekat pada maqasid Alquran merupakan nilai yang menjadikan Alquran mampu berjalan seiring dengan semangat zaman yang melingkupinya, serta tidak mengenal batas teritorial dan sekat-sekat kemanusiaan. Dengan demikian, Alquran sebagai kitab hidayah mampu menyentuh seluruh sendi kehidupan manusia, baik personal maupun kolektif, demikian halnya dengan penerapan hukum syariat, tak lekang oleh perubahan waktu dan tempat akibat penerapan nilai-nilai universal sebagai hasil terapan dari maqashid Alquran.

${ }^{64}$ Syamsul Wathani, Konfigurasi Nalar Tafsir Al Maqasidi; Pendekatan Sistem Interpretasi journal Suhuf, vol 9, No 2, Desember 2016. h.297 


\section{KONSEPTUALISASI TAFSIR MAQASID}

Sebagaimana telah dijelaskan terdahulu bahwa paradigma tafsir maqasidi merupakan paradigma baru dalam wacana tafsir Alquran. Paradigma tafsir ini memiliki asumsi dasar bahwa produk pemahaman terhadap nash Alquran harus merepresentasikan tujuan dari nash tersebut yaitu tercapainya mashlahat untuk manusia di dunia dan akhirat. Oleh karena itu, setiap mufassir dituntut untuk menemukan hikmah yang menjadi tujuan dari nash, mengungkapkan kembali makna-makna Alquran agar lebih aplikatif dan dinamis, memberi interpretasi yang sesuai tanpa mengorbankan teks, sekaligus tanpa mengorbankan kepribadian, budaya bangsa, dan perkembangan positif masyarakat. ${ }^{65}$

Permasalahan selanjutnya adalah bagaimana cara menemukan hikmah yang menjadi tujuan dari nash tersebut? ${ }^{66}$ Pada

\footnotetext{
${ }^{65}$ M. Quraish Shihab, Membumikan Al-Qur'an (Bandung : Mizan, 2013), h. 134.

${ }^{66}$ Dalam kaitan dengan upaya menemukan maqasid dari nash, mengutip pendapat al-Syatibi dalam al Muawafaqat, Asafri mengatakan bahwa para ulama terbagi kepada tida pandangan yang berbeda-beda. Pertama, ulama yang berpendapat bahwa maqasid al-syari'ah adalah suatu yang abstrak, tidak dapat diketahui kecuali melalui petunjuk Tuhan dalam bentuk zahir lafal yang jelas, pandangan ini dipeloori oleh kalangan mazhab Zahiriyyah. Kedua, ulama yang tidak menempuh pendekatan zahir al-lafz dalam mengetahui maqasid al-syari'ah. Kelompok ini terbagi kepada dua, yaitu kelompok Bathiniyyah yang memandang maqasid bukan dalam bentuk zahir, juga bukan dipahami dari tunjukan zahir al lafz. Maqasid merupakan hal lain yang ada dibalik tunjukan zahir al-lafz yang terdapat dalam semua aspek syariat, sehingga tak seorang pun dapat berpegang dengan zahir al-lafz. Kelompok kedua adalah ulama al-Muta'ammiqin fi al qiyas, mereka memandang zahir al lafz bukan tunjukan mutlak, tetapi maqasid harus dikaitkan dengan pengertian-pengertian lafal itu sendiri. Apabila terdapat pertentangan zahir al-lafz dengan nalar, maka yang diutamakan adalah pengertian nalar, baik atas dasar keharusan menjaga kemaslahatan atau tidak. Adapun pandangan ketiga dari ulama yang melakukan penggabungan dua pendekatan (zahir al-lafz dan pertimbangan makna/'illah) dalam suatu bentuk yang tidak merusak zahir al-lafz dan tidak pula merusak kandungan makna 'illah, agar syariah tetap berjalan secara harmoni tanpa kontradiksi-kontradiksi. Pandangan terakhir ini dikenal dengan ulama al-Raskhin. Lihat al-Syatibi dalam Asafri Jaya Bakri, h.89-90
} 
kenyataannya hikmah bisa diambil dari satu ayat Alquran saja sudah bisa beraneka ragam, apalagi pada ayat-ayat memungkinkan untuk multi tafsir seperti ayat-ayat mutasyabihat. Sebagai penggagas teori maqashid al-syari'ah, imam al-Syatibi sebagaimana dikutip Asafri bahwa bagi siapa saja yang ingin memahami maksud syariat yang terdapat dalam nash terdapat beberapa langkah-langkah yang harus dilalukan, yaitu: ${ }^{67}$

a. Melakukan analisis terhadap lafal perintah dan larangan

Menurut al-Syatibi bahwa sesuatu hal yang diperintahkan berarti ada tujuan yang dimaksudkan ketika mewujudkan perintah tersebut.Sebaliknya, sesuatu yang dilarang, berarti ada maksud dan tujuan yang ingin dicapai ketika sesuatu yang dilarang itu dijauhi dan tidak dikerjakan. Untuk itu mengamati perintah dan larangan secara hakiki, dalam arti tidak mengaitkannya pada permasalahan yang lain adalah langkah awal yang perlu dilakukan.

b. Menelaah 'illat yang terdapat dalam perintah dan larangan.

Mengetahui maksud nash bisa juga dengan memahami kenapa sesuatu itu diperintah dan/atau dilarang. Kenyataannya, ada 'illat yang secara jelas tertulis dan ada juga yang tidak tertulis.AlSyatibi berpendapat, jika 'illat itu diketahui maka harus mengikuti peintah dan larangan yang jelas tersebut agar tujuan yang memang sudah jelas dapat dicapai. Jika 'illat nya tidak terlihat secara jelas, maka kita harus menyerahkan tujuan-tujuan itu kepada tuhan sebagai pencipta syariat (bertawaqquf) dengan dua sikap: (1) tidak melakukan perluasan cakupan terhadap yang telah ditetapkan dalam nash. Karena upaya itu bisa disebut sebagai menetapkan hukum tanpa dalil. (2) boleh melakukan perluasan cakupan apabila dimungkinkan tujuan hukum dapat diketahui.

${ }^{67}$ Ibid, $92-103$ 
c. Menganalisa sikap diam al-Syari dari pensyariatan sesuatu (assukut 'an syar'iyyah al-a'mal ma'a qiyam al-ma'na al-muqtada lahu). ${ }^{68}$

Al-Syatibi nampaknya menyadari bahwa pada perkembangannya akan ada masalah-masalah hukum yang tidak dibahas atau tidak ditemukan pembahasannya secara zahir dalam nash, di mana masalah-masalah itu pada hakekatnya bisa berdampak positif untuk kehidupan manusia.

Langkah yang hampir serupa ditawarkan oleh Ibnu 'Asyur, namun beliau memberikan catatan penting sebelum mengemukakan cara-cara untuk mengetahui maqasid al-syari'ah. Ibnu 'Asyur mengatakan bahwa penjelasan yang akan ia kemukakan tentang cara-cara untuk mengetahui maqasid bukanlah merupakan ketetapan yang bersifat absolut, akan tetapi cara-cara tersebut merupakan indikasi adanya maqasid al-syari'ah dalam penetapan suatu hukum. Menurutnya pula, para pengkaji maqasid al-syari'ah harus bersifat

\footnotetext{
${ }^{68}$ Diamnya nash dalam suatu masalah menjadi dua: diam karena tidak ada motif dan diam meskipun ada motif. Diam karena tidak ada motif maksudnya adalah suatu nash tidak membahas suatu masalah karena memang tidak terdapat faktor pendorong nash untuk memberikan ketetapan pada masalah itu. Seperti hal-hal yang datang setelah Nabi wafat, misalnya pengumpulan mushaf, penggajian bagi amir dan pejabat dari bait al-mal dan masalah lainnya. Sedangkan diam meski ada motif adalah tidak menetapkannya suatu nash pada suatu masalah meskipun terdapat faktor yang sebenarnya mendorong nas tersebut memberikan sikap atas masalah itu. Hal ini menurut al-syatibi menunjukkan bahwa nash menghendaki sesuatu itu harus apa adanya, dalam arti tidak melakukan penambahan atau pun pengurangan, apa yang ditetapkan itulah tujuan yang diinginkan nash. Seperti contoh tidak ditetapkannya sujud syukur sebagai suatu syariat karena hal ini tidak dilakukan oleh Nabi Muhammad saw di masanya, sedangkan ketika itu faktor pendorong untuk melakukan ini seperti realisasi rasa syukur terhadap nikmat senantiasa tak terpisahkan oleh kehidupan manusia, kapan pun dan di manapun. Dengan demikian sikap diam nash atas hal ini menunjukkan bahwa tidak disyariatkannya sujud syukur pada masa nabi mengandung tujan bahwa memang hal tersebut tidak disyariatkan. Lihat, Asafri, h. $99-102$
} 
objektif, netral dan tidak fanatik terhadap pendapat dan hasil ijtihad sebelumnya dalam menetapkan tujuan di balik pensyariatan. ${ }^{69}$

Adapun menurut ibnu 'Asyur, cara-cara dalam mengetahui maqasid al-syari' ah adalah: ${ }^{.0}$

1. Melakukan observasi secara induktif (istqra'), yaitu mengkaji syariat dari semua aspek.

Observasi ini dibagi menjadi dua bagian, yaitu pertama, mengamati, mengkaji dan menelaah hukum-hukum yang telah diketahui 'illat (alasan) hukumnya. Cara ini akan mempermudah untuk menemukan dan menyimpulkan maksud yang terkandung di dalam hukum-hukum tersebut. Kedua, meneliti dalil-dalil hukum yang sama 'illatnya, hingga memiliki keyakinan bahwa 'illat tersebut adalah tujuan (maqasid) yang dikehendaki oleh pembuat hukum.

Langkah pertama diatas senada dengan apa yang dikatakan Qardhawi dalam melihat maksud dari satu hukum yang terdapat dalam teks Alquran. Menurutnya untuk melihat hal tersebut dibutuhkan langkah sebagai berikut: Pertama, meneliti setiap 'illat teks Alquran dan Sunnah, seperti pada surat al-Hasyr: 7", maksud dari pembagian fai terhadap golongan-golongan lemah dan membutuhkan -sebagaimana dalam ayat tersebut- adalah agar harta bisa dimanfaatkan lebih luas. Sehingga, orang-orang kaya tidak memonopoli harta tersebut dan menggunakannya di antara mereka saja. ${ }^{71}$ Kedua, meneliti, mengikuti dan memikirkan hukum-hukum partikular. Untuk kemudian menyatukan antara satu hukum dengan hukum yang lain. Hal ini juga berlaku pada teks yang membahas tema yang berkaitan, agar penelitian bisa mendapatkan maksud-

\footnotetext{
${ }^{69}$ Muhammad Tahir Ibnu 'Asyur, Maqasid al-Syari'ah al-Islamiyah, ed. Muhammad al-Tahir al-Misawi, Cet II (Yordania: Dar al-Nafais, 2001) h.189-190

${ }^{70}$ Ibid, 190-194

${ }^{71}$ Yusuf al-Qaradhawi, Fiqih Maqashid Syariah: Moderasi Islam antara Aliran Tekstualis dan Aliran Liberal, (Jakarta: Pustaka al-Kautsar, 2006), hlm. 24
} 
maksud umum yang menjadi maksud Allah dalam membuat hukum atau menjadikan teks-teks tersebut. ${ }^{72}$

2. Menggunakan dalil-dalil yang secara tekstual dan tersurat telah jelas mengandung makna dan memiliki tujuan tertentu.

Maqasid yang dapat ditemukan secara langsung dari dalildalil al-Quran secara jelas (sarih) serta kecil kemungkinan untuk dipalingkan dari makna zahir-nya. Seperti bunyi ayat 183 surat alBaqarah tentang kewajiban puasa "kutiba 'alaykum al-siyam." Pada ayat ini, sangat kecil kemungkinan mengartikan kata "kutiba" dengan arti selain "diwajibkan," dan tidak mungkin dimaknai sebagai "ditulis."

3. Menggunakan hadis-hadis mutawatir ${ }^{73}$, baik hadis mutawatir yang bersifat maknawiah (al-mutawatir al-maknawi) maupun yang bersifat amaliah (al-mutawatir al- 'amali).

Tujuan yang didapatkan dari dalil-dalil hadis mutawatir maknawiah adalah tujuan yang diperoleh dari pengamatan mayoritas sahabat terhadap perbuatan Nabi, seperti khutbah hari raya yang dilaksanakan setelah salat.Sedangkan tujuan yang didapatkan dari dalil-dalil hadis mutawatir amaliah adalah tujuan yang diperoleh dari kesaksian sahabat melalui perbuatan-perbuatan Nabi, seperti hadis yang diriwayatkan oleh sahabat dan menyimpulkan bahwa Nabi menginginkan suatu kemudahan dalam setiap perbuatannya.

Penggunaan hadis mutawatir diatas, kurang lebih sama dengan konsep pengamatan konteks asbab al-nuzul suatu ayat. Sebagaimana yang dikemukakan oleh Quraish Shihab bahwa salah satu cara menemukan makna yang menjadi tujuan sebuah teks

\footnotetext{
${ }^{72}$ Ibid, h.28

${ }^{73}$ Hadis mutawatir ialah hadis yang diriwatkan oleh sekelompok orangyang secara adat tidak mungkin berdusta — dalam meriwayatkan suatu Hadis. Lihat Mahmud al-Tahhan, Taisir Mustalah al-Hadith, (Jakarta; Dar al-Hikmah, t.th.), h. 19
} 
adalah asbab al-nuzul yang mencakup peristiwa, pelaku, dan waktu. Beliau menyayangkan bahwa dalam hal asbab al-nuzul seringkali aspek waktu diabaikan, padahal asbab al-nuzul merupakan data yang membantu mengetahui dan memahami maksud suatu teks dengan cara mengqiyaskan persitiwa pada saat turunnya ayat dengan keadaan sekarang. Tanpa memperhatikan waktunya, maka tidak relevan untuk dianalogikan (diqiyaskan).Sebab sebagaimana telah disepakati bahwa ayat Alquran tidak turun dalam masyarakat yang hampa budaya, tanpa ada perstiwa yang mendahului atau bersamaan dengan turunnya ayat.Untuk itu, analogi yang digunakan hendaknya tidak terbatas oleh analogi yang dipengaruhi oleh logika formal (al-mantiq al-shuri) yang selama ini banyak dipengaruhi oleh para fuqaha. Tetapi analogi yang lebih lusa dari itu, yang meletakkan dipelupuk mata al-masalih al-mursalah dan yang mengantar kepada kemudahan pemahaman agama, sebagaimana halnya pada masa Rasulullah saw dan para Sahabat. Pengertian asbab al-nuzul dengan demikian dapat diperluas sehingga mencakup kehidupan kondisi sosial pada masa turunnya Alquran dan pemahamannya pun dapat dikembangkan melalui kaidah yang pernah dicetuskan oleh para ulama terdahulu, dengan mengembangkan qiyas. $^{74}$

Selain pengamatan asbab al-nuzul, Quraish Shihab juga menawarkan konsep $T a$ 'wil. Pemahaman literal terhadap teks ayat Alquran tidak jarang menimbulkan problem atau ganjalan-ganjalan dalam pemikiran, apalagi ketika pemahaman tersebut dihadapkan dengan kenyataan sosial, hakikat ilmiah, atau keagamaan.Dahulu, ketika tidak bisa memberikan definisi yang memuaskan atau yang sejalan dengan pemahaman perkembangan masyarakat, ulama cukup mengatakan “wallahu a'lam bi muradihi”.Hal ini tentu saja bukan merupakan suatu hal yang salah, tetapi tentunya tidak

\footnotetext{
${ }^{74}$ Quraish Shihab, Membumikan al-Qur'an..., h. 136
} 
memuaskan banyak pihak.Karena itu, sedikit demi sedikit sikap seperti itu berubah dan para mufassir akhirnya beralih pandangan dengan jalan menggunakan ta'wil, tamsil dan metafora.Memang, literalisme seringkali mempersempit makna, berbeda dengan penta'wilan yang memperluas makna sekaligus tidak menyimpang darinya. ${ }^{75}$ Hanya saja yang perlu digaris bawahi adalah tidak tepat menta'wilkan suatu ayat, semata-mata berdasarkan pertimbangan akal dan mengabaikan faktor kebahasaan yang tedapat dalam teks.Terlebih bila bertetangan dengan prinsip kaidah-kaidah kebahasaan. Karena hal ini berarti mengabaikan ayat itu sendiri. ${ }^{76}$

Berdasarkan langkah-langkah yang ditawarkan oleh bebrapa tokoh maqashidiyyun diatas dalam menemukan hikmah yang menjadi tujuan suatu teks Alquran, maka dapat disusun tata-kerja penafsiran yang menggunakan pendekatan maqasid dalam memahami Al-Quran, dengan tahapan sebagai berikut:

1. Analisis kebahasaan.

Pada tahap ini, analisis dilakukan terhadap apa yang dikatakan teks dengan memperhatikan kaidah-kaidah kebahasaan. Meliputi bahasa teks, makna teks, bentuk dan konteks teks dan hubungan dengan teks lainnya. Analisis ini memiliki posisi penting dalam hal penggalian makna ayat, bahkan bagi al-Syatibi dijadikan syarat mutlak dalam memahami maksud syariat yang terdapat dalam nas, hal ini dikarenakan bahasa arab memiliki pola penyampaian yang khusus dibanding bahasa lain, contoh sederhanya adalah, penulisan lafal am yang dimaksudkan untuk sesuatu yang khas, atau lafal khas yang dimaksudkan pada sesuatu yang khas. ${ }^{77}$

2. Identifikasi Makna Ayat

${ }^{75}$ Ibid, 137

${ }^{76}$ Ibid, 138

77 Al-Syatibi, al-Muwafaqat fi ushul as-Syariah, (Kairo: Mustafa Muhammad, t,th), jilid II, h.65 
Tahapan ini hanya bertujuan menemukan makna teks yang sesuai konteks pewahyuan.Indentifkasi makna dapat dilakukan dengan menyesuaikan yang dengan penggunaan terma serupa dalam Alquran dan mempertimbangkan sisi historis dan sebab turunnya suatu ayat al-Quran, baik mikro maupun makro.

3. Eksplorasi maqasid al-syari'ah

Tahapan ini menjadi ciri khas penafsiran Al-Quran berbasis maqasid. Mufasir tidak hanya berhenti pada penggalian makna sesuai konteks pewahyuan, akan tetapi juga menggali makna yang sesuai dengan tujuan syariat (maqasid). Makna tersebut selain menjadi pendamai bila mana terjadi kesenjagan antara makna konteks pewahyuan dengan konteks yang dipahami, juga berfungsi sebagai pengikat antara makna teks tersebut dengan konteks kekinian.

4. Kontekstualisasi Makna

Tahapan ini menjadi tahap pengembangan signifikansi penafsiran maqasid terhadap persoalan, masalah dan kebutuhan pada masa kini yang tampak relevan dengan pesan teks yang ditafsirkan. Makna ayat yang sudah tersingkap, dengan mengacu pada tujuan syariat yang sudah dieksplorasi sebelumnya, kemudian direfleksikan sesuai konteks ayat akan diterapkan. Hanya saja kontekstualisasi itu tidak diberlakukan pada semua aspek pemahaman teks-teks Islam, ada batas-batas yang harus dijaga.

\section{CONTOH APLIKASI TAFSIR MAQASHIDI}

Pada bagian ini, akan diketengahkan salah satu contoh dalam aplikasi corak tafsir maqasidi, yaitu pada permasalahan tentang poligami. Poligami atau ta'addut al-zawjat bisa diartikan sebagai ikatan perkawinan yang salah satu pihak (laki-laki; suami) mengawini beberapa (lebih dari satu) istri dalam waktu yang 
bersamaan. Selain itu ada juga poliandri lawan dari poligami, yaitu istri memilki beberapa orang suami dalam waktu yang bersamaa. ${ }^{78}$

Pada dasarnya, praktek poligami sudah dilakukan dalam tradisi pra-Islam (Arab), dimana kala itu seorang laki-laki bisa melakukan perkawinan dengan jumlah istri yang tidak terbatas.Para laki-laki memilki hak penuh untuk memiliki dan memilih siapa dan berapa yang menjadi istirnya.Untuk itu, dengan misi keadilan yang diusung, Islam datang merubah praktek demikian dengan memberikan jumlah batasan yang dapat dijadikan istri serta menekankan persyaratan yang mesti dipertimbangkan bagi suami. Dalam Alquran, selain Q.S. an Nisa: 3 yang membicarakan tentang ketentuan poligami beserta persyaratannya, juga pada surah yang sama ayat 129 menyangsikan terwujudnya persyaratan tersebut.

Untuk itu, kedua ayat diatas nampak bertentangan, sehingga dibutuhkan penafsiran maqasidi yang berfungsi sebagai jembatan penghubung dalam mendamaikan ayat tersebut. Dalam hal ini menarik mempertimbangkan penafsiran maqasidi Rasyid Ridha, sebagaimana yang disarikan dari kuliah tafsir gurunya Muhammad Abduh, kemudian dituangkan dalam kitab tafsirnya al-Manar.

Konseptualiasi penafsiran maqasid Rasyid Ridha tentang poligami dapat teruraikan berdasarkan langkah kerja yang telah dirumuskan, yaitu; terkait masalah analisis bahasa, pada ayat ini tidak terlalu signifikan memunculkan perdebatan seputar kebahasaan, bahkan secara dalalah lafal' (dilalah al-lafz) yang menunjukkan implikasi langsung dari suatu bunyi bahasa atau nash dapat diterapkan pada ayat ini. Sehingga wajar jika sebagian mufassir menjadikan ayat ini sebagai dasar hukum poligami.Hanya saja mendasarkan pemahaman ayat pada langkah ini tidaklah cukup, melainkan diperlukan langkah selanjutnya pada tahap identifikasi makna ayat dan elaborasi hikmah yang menjadi maqasid ayat.

${ }^{78}$ Musda Mulia, Pandangan Islam Tentang Poligami (Jakarta: Lembaga Kajian Agama dan Gender, 1999), h.2 
Untuk identifikasi makna ayat, maka pemahaman atas konteks historis dan asbab al-nuzul ayat adalah unsur terpenting dalam tahapan ini. Bagi Rasyid Ridha, ayat 3 surat an-Nisa' ini diturunkan pasca terjadinya perang uhud, dimana saat itu banyak mujahid dan tentara muslim yang syahid di medan perang. Akibatnya, banyak anak yatim beserta ibunya yang terabaikan dan membutuhkan perlindungan dalam kehidupan, karena ditinggal mati oleh ayah dan suaminya. Atas dasar ini Rasyid Ridha berpendapat, bahwa ayat tersebut menjelaskan masalah hukum terkait dengan status wanita-wanita yang berada dalam kekuasaan walinya, sebagaimana yang diriwayatkan dalam al-Sahihain, Sunan al-Nasa'i dan al-Baihaqi serta tafsir Ibnu Jarir, Ibnu Munzir dan Ibn abi Hatim disebutkan bahwa 'Urwah Ibn al-Zubair pernah bertanya kepada 'Aisyah Ra, perihal ayat air. Lalu 'Aisyah menjawab bahwa yang dimaksud 'al-yatama' dalam ayat ini adalah wanita-wanita yang berada dalam kekuasaan walinya. Selain wali memiliki tugas unutk mengatur dan mengelola hartanya, Ia juga ikut menginginkan harta itu serta kecantikannya, sehingga wali tersebut berkeinginan untuk mengawininya berdasarkan harta dan kecantikannya, tanpa ingin memberikan mahar sebagaimana selayaknya. Maka dari situ, turunlah larangan untuk menikahi wanita-wanita tersebut, kecuali dengan komitmen untuk berlaku adil dan memberikan hak mahar yang semestinya. Kalau tidak demikian, diperbolehkan untuk menikahi lebih daripada wanita lain yang bukan dari kalangan wanita-wanita yatim tersebut. ${ }^{79}$ Dengan demikian, Penekanan untuk berlaku adil pada wanita-wanita tersebut menjadi makna utama dari pada ayat ini.Sedangkan makna keadilan pada ayat 129, adalah keadilan yang sifatnya lahiriah, bukan batiniyah yang bersumber pada perasaan hati, sehingga setiap orang tidak mampu untuk membagi perasaan batin, termasuk baginda Rasulullah SAW

${ }^{79}$ Muhammad Rasyid Ridha, Tafsir al-Qur'an al-Hakim (Kairo, Dar alManar, 1947), cet. Ke 2, vol. 4, h.344. 
sendiri.Sebab, pada masa akhir hidupnya, beliau pernah lebih condong terhadap salah satu istrinya (Aisyah Ra.) dibandingkan dengan para istri lainnya. ${ }^{80}$

Sedangkan tahap elaborasi maqashid al-syariah pada ayat ini dapat dilakukan dengan mempertimbangkan makna ayat yang telah ditemukan. Memang secara zahir dan eksplisit ayat ini memperbolehkan poligami, tetapi ajaran poligami yang terdapat dalam ayat ini merupakan salah satu alternatif dari sekian banyak alternatif lainnya untuk menegakkan keadilan dalam masyarakat, khususnya bagi perempuan yatim. Sehingga dapat ditetapkan bahwa prinsip keadilan dan anjuran untuk menegakkan keadilan merupakan maksud dan tujuan akhir dari ayat ini.

Terkait masalah hukum poligami ini, Rasyid Ridha juga menambahkan bahwa (1) dalam Islam tidak mewajibkan atau menganjurkan untuk melakukan praktek poligami, akrena kemungkinan-kemungkinan besar perbuatan zalim disalah satu pihak akan muncul, (2) Islam tidak secara mutlak menolaj poligami, namun tida pula terlalu longgar dalam hal ini, menimbang watak dasar laki-laki yaitu memiliki kemampuan dalam berbagai hal, termasuk juga dalam hal reproduksi, selain itu melihat jumlah perempuan yang semakin banyak akibat banyak pergolakan zaman dan melahirkan para janda-janda yang selayaknya diayomi dan diselamatkan, (3) Islam memberikan hukum mubah (boleh) dengan syarat ketat yang telah ditentukan, mengingat juga akan dampak buruk yang ditimbulkan. ${ }^{81}$

Berdasarkan keterangan diatas, dapat dikatakan bahwa Rasyid Ridha melihatnya bukan hanya dalam tataran normatif tetapi lebih kepada wilayah praktis.Dia berangkat dari situasi dan kondisi di sekitarnya yang acap kali menimbulkan kezaliman pada pihak

\footnotetext{
${ }^{80}$ Ibid, . h.148

${ }^{81}$ Rasyid Ridha, Nida' lil al-Jins al-Lathif; Huquq al-Nisa fi al-Islam (Beirut: Maktabah al-Islami, 1984), h. 45-46
} 
perempuan yang tidak menapatkan perlakuan adil.Namun bila perlakuan adil, jaminan keselamatan dan kehidupan bagi kaum janda dan anak yatim sebagai individu yang mempunyai hak dan kewajiban, serta terwujunya kemaslahatan sosial untuk menjaga stabilitas masyarakat dan bangsa, maka Rasyid Ridha membolehkannya. ${ }^{82}$

\section{PENUTUP}

Tafsir maqasidi merupakan tawaran metode baru dalam diskursus ilmu tafsir. Model penafsiran ini berusaha memelihara pesan universal al Quran, sehingga dapat lebih sesuai dengan tantangan dan tuntutan zaman (salihun li kulli zaman wa makan) dengan cara mengalihkan arah pandangan dengan melakukan pencarian pada maqāṣid al-Qur'ān yang universal. Nilai-nilai universal serta sifat keabadian ( $q a t^{\prime} i$ ) yang melekat pada maqasid ayat Alquran menjadikan metode penafsiran ini seringkali disamakan dengan paradigma tafsir kontekstual.

\section{DAFTAR PUSTAKA}

M. Quraish Shihab, Membumikan Alquran (Bandung: Mizan, 1989) Yudian Wahyudi, Ushul Fikih versus Hermeneutika, cet vi, (Yogyakarta: Nawasea Press, 2010)

M. Amin Abdullah, Falsafah Kalam di Era Postmodernisme, (Yogyakarta: Pustaka Pelajar, 1994)

Abdul Mustaqim dkk, Studi Alquran Kontemporer, (Yogyakarta: Tiara Wacana Yogya, 2002)

Thomas S. Khun, The Structur of Scientific Revolutions, terj. Tjun Surjaman, (Bandung: Remaja Rosda Karya, 2012)

${ }^{82}$ Abdul Majid Abd al-Salam, Visi dan Paradigma Tafsir al-Qur'an Kontemporer, terj. Moh. Maghfur (Jatim; Bangil: Al Izzah, 1997), h.112 
Ali Mudlofir, Paradigma Tafsir Tarbawi, jurnal Al-Tahrir Vol.11, No. 2 November 201

Moh. Nuhakim, Metodologi Studi Islam (Malang: UMM Press, 2006)

www.kbbi.web.id

Ibn Mandzur, lisan al-'Arab, ditahqiq oleh Amir Ahmad Haidar, cet. Ke-2, jilid V (Beirut: Dar al-Kutub al-'Ilmiah, 2009)

Ahmad Warson Munawwir, al-Munawwir, (Indonesia: Pustaka Progressif, 1997)

Nashruddin Baidan, Wawasan Baru Ilmu Tafsir , (Yogyakarta: Pustaka Pelajar, 2005)

Badr al-Din Muhammad ibn 'Abdullâh ibn Bahadir al-Zarkasyi, alBurhan fi 'Ulum al-Qur'an, juz ke-1 (Beirut: Dar alMa'rifah, 1957)

Jaser Auda, Membumikan Hukum Islam melalui Maqasid Syariah, terj. Rosidin dan Ali Abd Mun'im, (Bandung: Mizan, 2015)

Abdul Karim Hamidi, Al Madkhal ila Maqasid Alquran, (Riyadh:

Maktabah ar Rusyd, 2007)

Munawir, Pandangan Dunia Alquran; Telaah Terhadap Prinsip-

Prinsip Universal Alquran, Penelitian Individual, (Purwokerto: IAIN Purwokerto, 2015)

Halil Thahir, Ijtihad Maqasidi; Rekonstruksi Hukum Islam Berbasis Interkonesitas Maslahah (Yogyakarta: LKiS, 2015)

Imam Mawardi, Fiqhi Minoritas; Fiqh Al Aqalliyat dan Evolusi Maqasid al-syari'ah dari Konsep ke Pendekatan (Yogyakarta: LKiS, 2010)

Ahmad al-Raisuni, Nazhariyyat al-maqashid inda al-imam alSyathibi, (Libanon: al-Mussasah al-Jami'ah li Dirasat wa alNasyr wa al-Tauzi', 1992)

Yusuf al Qardhawi, Kayfa Nata'amal Ma'a Alquran, (Kairo: Daar as Syuruq, 2000) Cet 3. 
Muhammad Chirzin, Kearifan Alquran, (Yogyakarta : Pilar Media, 2007)

Wasfi 'Asyur Abu Zaid, at-Tafsir al-Maqashid li Suwar Alquran alKarim, makalah diunduh dari www.alukah.net

Radwan Jamal el-Atrash dan Nahswan Abdo Khalid Qaid, al-Jazur at-Tarikhiyyah li at-Tafsir al-Maqashidi li Alquran alKarim, Majallah al-Islam fi Asiya no. 1 (Malaysia: UII, 2011)

Satria Effendi M. Zein, Ushul Fiqih, (Jakarta: Prenada Media, 2005), Cet. 1

Al Izz bin Abd al Salam, Qawaid al Ahkam fi Mashalih al Anam, (Damshiq: Dar al Kutub al Ilmiyyah, 1992), vol 2

Syams al-Din Ibn al Qayyim, I'lam al Muwaqqi'in, ed Taha Abdul Rauf Sa'd (Beiru: Dar al Jil, 1973), vol 1

Umayah, Tafsir Maqashidi; Metode Alternatif Dalam Penafsiran Alquran, jurnal Diya al-Afkar Vol.4 No.01, Juni 2016

Abdullah bin Bahyyah, 'Alaqah Maqashid al-syari'ah bi Ushul alFiqh (London: Al-Furqan Islamic Heritage Foundation, 2006)

Al-Syatibi, dalam Asafri Jaya Bakri, Konsep Maqashid al-syariah menurut al-syatibi, (Jakarta: Raja Grafindo, 1996)

Abdullah Saeed, Paradigma, Prinsip dan Metode Penafsiran Kontekstualis atas Alquran, terj. Lien Iffah (Yogyakarta: Lembaga Ladang Kata, 2015)

Ahmad al-Raysuni, Ijtihad antara Teks, Realitas dan Kemaslahatan Sosial, terj. Ibnu Rusydi, (Jakarta: Erlangga, 2002)

Abu Hamid al-Ghazali, al-Mustashfa min 'Ilm al-Ushul, jilid I (Beirut: Dar al Kutub al-'Ilmiyyah, 1983)

Syamsul Wathani, Konfigurasi Nalar Tafsir Maqasidi; Pendekatan Sistem Interpretasi journal Suhuf, vol 9, No 2, Desember 2016 
Muhammad Tahir Ibnu 'Asyur, Maqasid al-Syari'ah al-Islamiyah, ed. Muhammad al-Tahir al-Misawi, Cet II (Yordania: Dar al-Nafais, 2001)

Yusuf al-Qaradhawi, Fiqih Maqashid Syariah: Moderasi Islam antara Aliran Tekstualis dan Aliran Liberal, (Jakarta: Pustaka al-Kautsar, 2006)

Saifullah, Nuansa Inklusif Dalam Tafsir al-Manar (Jakarta: Badan Litbang dan Diklat Kemenag, 2012)

Mahmud al-Tahhan, Taisir Mustalah al-Hadith, (Jakarta; Dar alHikmah, t.th.)

As-Syatibi, al-Muwafaqat fi ushul as-Syariah, (Kairo: Mustafa Muhammad, t,th), jilid II

Musda Mulia, Pandangan Islam Tentang Poligami (Jakarta: Lembaga Kajian Agama dan Gender, 1999), h.2

Rasyid Ridha, Nida' lil al-Jins al-Lathif; Huquq al-Nisa fi al-Islam (Beirut: Maktabah al Islami, 1984), h. 45-46

Abdul Majid Abd al Salam, Visi dan Paradigma Tafsir Alquran Kontemporer, terj. Moh. Maghfur (Jatim; Bangil: Al Izzah, 1997) 